\title{
ESTIMATION OF AGE FROM DRY HUMAN MANDIBLES AND CORRELATION OF AGE WITH MANDIBULAR PARAMETERS
}

\author{
Humaira Zainab ${ }^{1}$, Veer Bhadrappa Nandyal ${ }^{2}$
}

1 Postgraduate Student, Department of Anatomy, Mahadevappa Rampure Medical College, Gulbarga, Karnataka, India. 2Professor and HOD, Department of Anatomy, Mahadevappa Rampure Medical College, Gulbarga, Karnataka, India.

\author{
BACKGROUND \\ Age determination from a human bone is an important role in forensic as well as anthropology study fields. As mandible is one of \\ the largest and hardest of facial bones, it commonly resists post-mortem damage, hence is an important source for age assessment. \\ The aims of the study are- \\ 1. To estimate age of 100 dry human mandibles by using mandibular parameters, i.e. Gonial angle, Length of ramus, Bigonial \\ width and Bicondylar breadth. \\ 2. To correlate age with the mandibular parameters.
}

ABSTRACT

\section{MATERIALS AND METHODS}

The descriptive study of 100 dry human mandibles were collected from Department of Anatomy and from $1^{\text {st }}$ phase MBBS students of 2017 batch, MRMC, Kalaburgi, Karnataka. Mandibles were first separated as male and female mandibles by using morphological features.

1. Eversion/ Inversion of gonial angle.

2. Prominence of muscular markings.

After these mandibles were divided into various age groups by using the inference from other author's study done on mandibles in living subjects based on degree of gonial angle, further readings were subjected to statistical analysis.

\section{RESULTS}

There was statistically very highly significant difference of mean right and mean left gonial angle in degrees in age groups $(p<0.001)$. Mean of right and left gonial angle were significantly higher in higher age groups. There was statistically very highly significant difference of mean length of right ramus and mean length of left ramus in cms in age groups $(p<0.001)$. Mean length of right and left ramus were significantly lower in higher age groups. There was no statistically significant difference of mean bicondylar breadth and mean bigonial width in cms in age groups $(\mathrm{p}>0.05)$. Study reveals highly significant positive correlation between age and gonial angle $(\mathrm{p}<0.01)$. Higher the mandibular angle with respect to age is also higher. There is highly significant negative correlation between age and length of ramus $(\mathrm{p}<0.01)$. Lower the length of ramus with respect to age is higher. There is no significant correlation between age and bicondylar breadth and bigonial width. Mean of all parameters were taken. The observations were recorded and subjected to statistical analysis of One-Way ANOVA test and age was estimated using regression equation.

\section{CONCLUSION}

The result concluded that mandibular angle and length of ramus can be effectively used in identification of age.

\section{KEY WORDS}

Mandible, Gonial Angle, Length of Ramus, Bicondylar Breadth, Bigonial Width.

HOW TO CITE THIS ARTICLE: Zainab H, Nandyal VB. Estimation of age from dry human mandibles and correlation of age with mandibular parameters. J. Evolution Med. Dent. Sci. 2018;7(36):4027-4031, DOI: 10.14260/jemds/2018/899

\section{BACKGROUND}

Skeleton has always aided in genetic, anthropological, odontological and forensic investigation of living and nonliving individual. ${ }^{1}$

Chronological age assessment is an important part of medicolegal practice. The procedure of age determination is

'Financial or Other Competing Interest': None.

Submission 24-07-2018, Peer Review 17-08-2018,

Acceptance 25-08-2018, Published 03-09-2018.

Corresponding Author:

Dr. Humaira Zainab,

Postgraduate Student,

Department of Anatomy,

M. R. Medical College,

Sedam Road, Gulbarga, Karnataka, India.

E-mail: zainabhumaira@gmail.com zainabhumaira@yahoo.com

DOI: $10.14260 /$ jemds/2018/899 complex and involve the consideration of many factors. Changes related to chronological age are seen in both hard and soft tissues. $(2,3)$

A number of methods for age determination have been proposed. These can be classified in four categories including clinical, histological, chemical and radiological analysis. In the living persons, any or all the above methods can be used to determine age in cases where actual age is not known or is to be confirmed. However, in case of a dead person, postmortem changes such as decomposition, mutilation or skeletonisation may make identification progressively more difficult, almost to the point of impossibility. 4

Mandible bone, which form the lower jaw plays an indispensable role in determining an individual's facial features. It undergoes constant remodeling and morphological alteration throughout the lifetime of a person. The influence of aging on the remodeling changes of the mandible has been shown by longitudinal studies. ${ }^{5}$ 
Various authors have described number of changes that takes place in the morphology of the human mandible with advancing age. One of the prominent changes that have been suggested is the change in gonial angle. The angle between ramus and the corpus of the mandible is called gonial angle. Any change in gonial angle is largely produced by ramus remodelling and is determined by the remodeling direction of the ramus with its condyle. Very few studies have been carried out to correlate changes in gonial angle with age.(6-10)

Research into age determination from dental radiographs largely consists of the use of lateral cephalograms and orthopantomograms with the majority of papers investigating the gonial angle and few researching ramus height and bigonial width.

Thus, the present study is aimed to estimate age using mandibular parameters, i.e. gonial angle, length of ramus, bicondylar breadth, bigonial width and their correlation with age.

\section{MATERIALS AND METHODS}

The present study was a descriptive study conducted in the Department of Anatomy, MRMC, Kalaburgi, Karnataka, India and was approved by the Institutional Ethical Committee. The sample consist of 100 dry human mandibles from the Department of Anatomy and also from MBBS students of 2017 batch.

Mandibles were first identified and divided into male and female mandibles by using two morphological parameters-

1. Inversion or eversion of gonial angle.

2. Prominence of muscular markings.

\section{Study Design}

It is a descriptive study.

\section{Inclusion Criteria}

Study includes all intact, edentulous, non-edentulous mandibles.

\section{Exclusion Criteria}

Mandibles, which are broken are excluded from the study.

\section{Statistical Method}

Statistical data was analysed by using IBM-SPSS 20.0 version software.

For Age wise comparison of variables, ANOVA test was applied.

Regression analysis was used to estimate age and correlation coefficient was applied to know relation between variables.

If $\mathrm{p}$-value is $<0.05$, it is considered as significant.

Out of 100, 65 were male mandibles and 35 were female mandibles. Further mandibles were distributed in age groups based on other author's study by using gonial angle in degree as-

\begin{tabular}{|c|c|c|}
\hline Age Group & Age Range in Years & Gonial Angle in Degree \\
\hline Group-1 & $20-29$ & $<15^{0}$ \\
\hline Group-2 & $30-39$ & $115^{0}-117^{0}$ \\
\hline Group-3 & $40-49$ & $118^{0}-121^{0}$ \\
\hline Group-4 & $50-59$ & $122^{0}-124^{0}$ \\
\hline Group-5 & $60-69$ & $>125^{0}$ \\
\hline
\end{tabular}

Age was estimated and correlation of age with parameters were studied.

Measurements were done using protractor, scale, vernier caliper, pencil, paper and gloves.

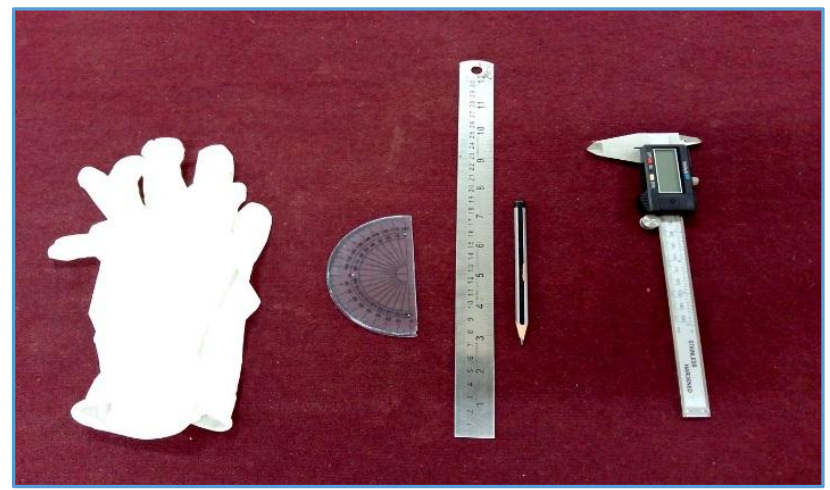

Figure 1

\section{Gonial Angle}

Measured as the angle between the base and the tangent drawn along the posterior border of the ramus, touching the posterior most point on the condyle and the posterior most point on the posterior border.

\section{Length of Ramus}

Maximum length of Ramus from base of mandible to mandibular notch.

\section{Bigonial Width}

It is the straight distance between two gonia.

\section{Bicondylar Breadth}

It is the straight distance between the most lateral points on the two condyles.

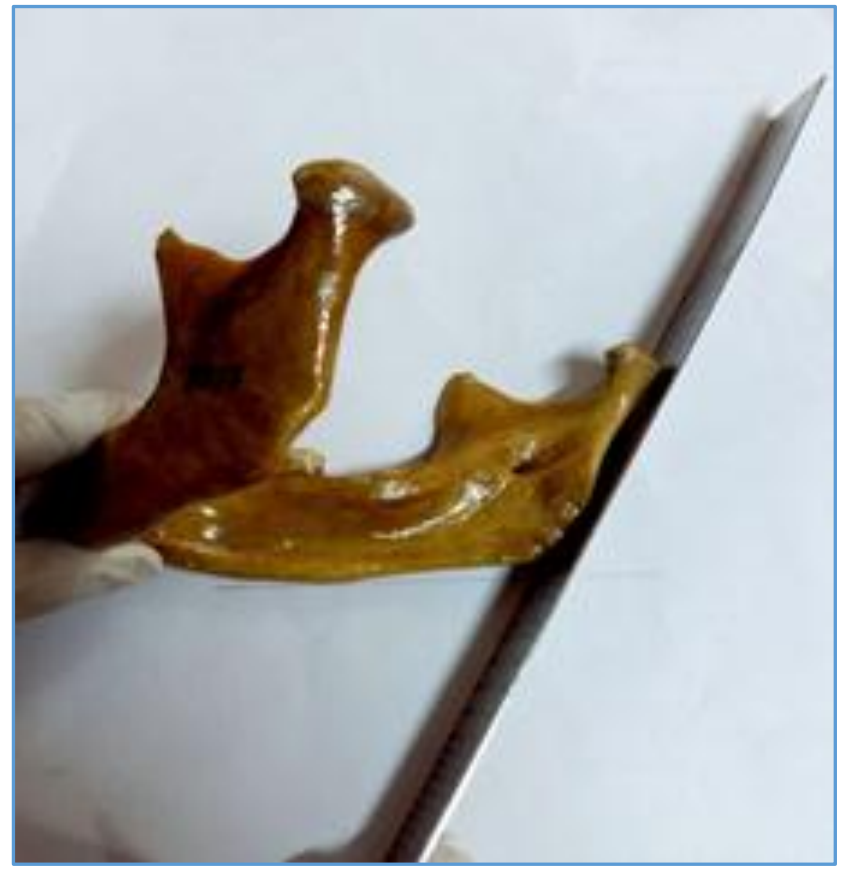

Figure 2. Showing Gonial Angle 


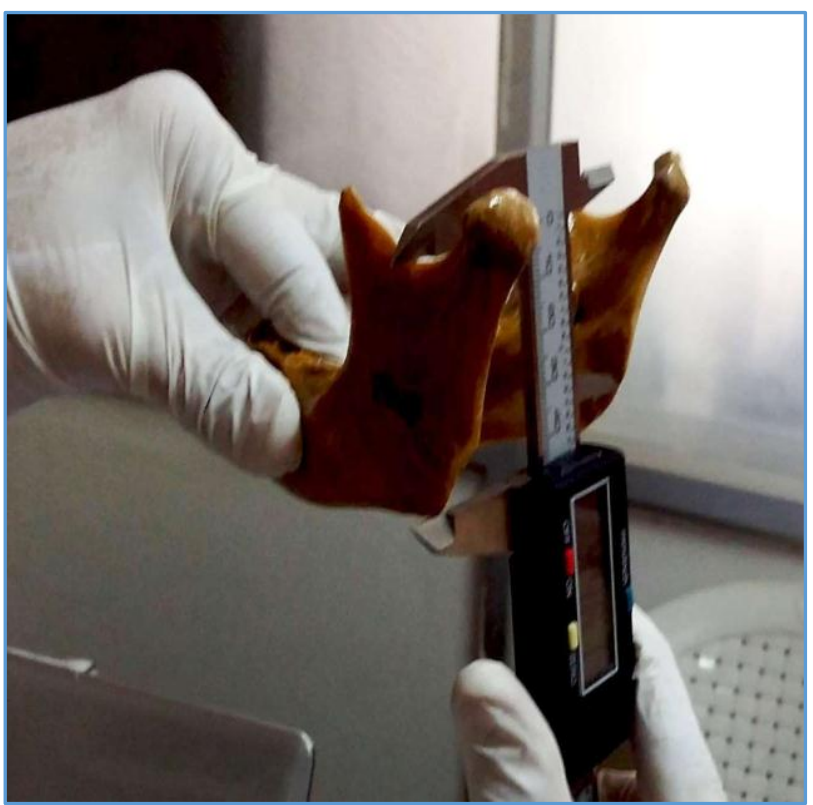

Figure 3. Showing Length of Ramus

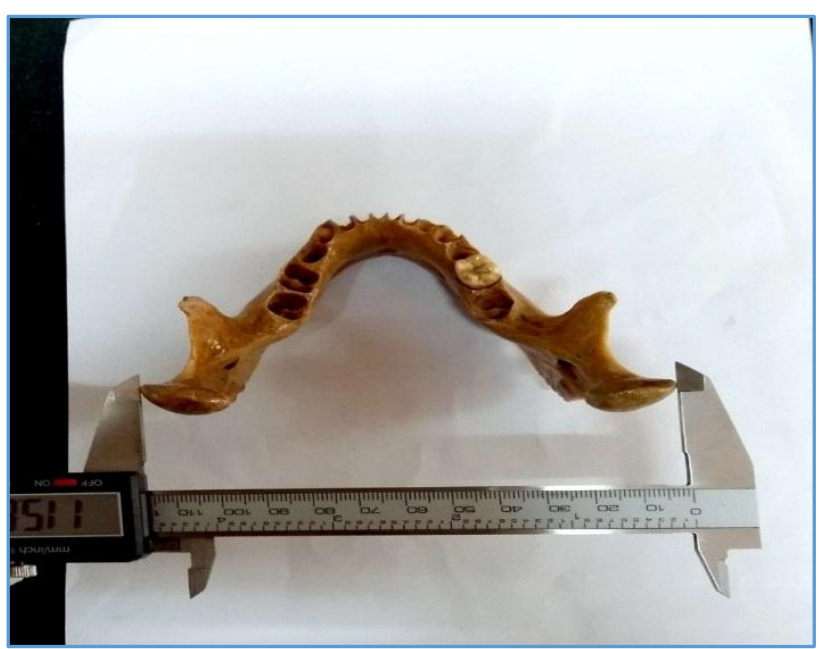

Figure 4. Showing Bicondylar Breadth

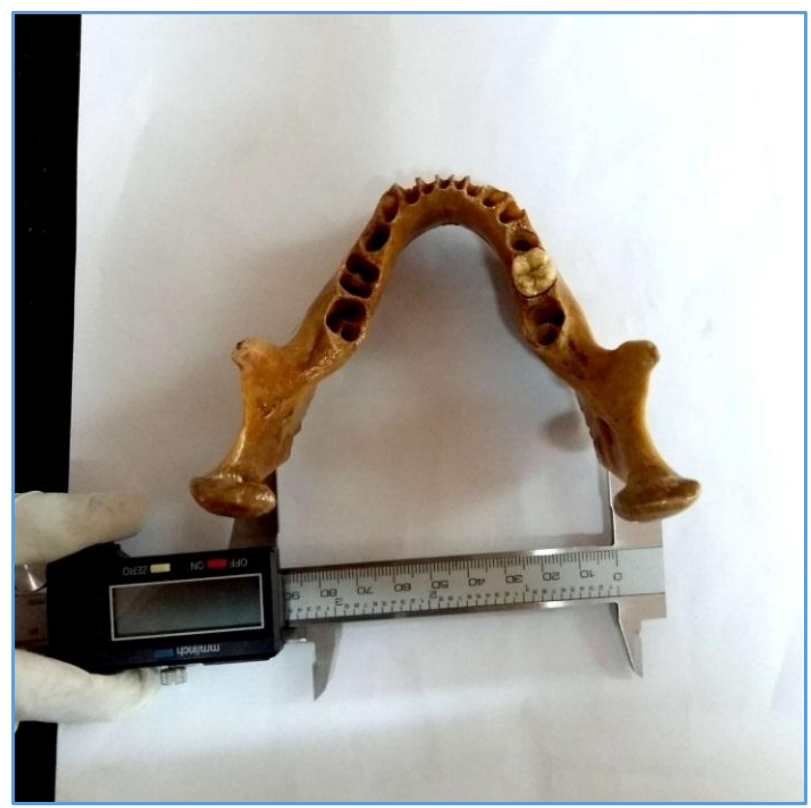

Figure 5. Showing Bigonial Width
RESULTS

\begin{tabular}{|c|c|c|c|c|c|c|c|}
\hline & $\begin{array}{c}20-29 \\
(\mathrm{~N}=36)\end{array}$ & $\left|\begin{array}{l}30-39 \\
(\mathrm{~N}=7)\end{array}\right|$ & $\begin{array}{r}40-49 \\
(\mathrm{~N}=15)\end{array}$ & $\begin{array}{l}50-59 \\
(\mathrm{~N}=9)\end{array}$ & $\begin{array}{c}60-69 \\
(\mathrm{~N}=33)\end{array}$ & \multirow{2}{*}{$\begin{array}{c}\text { ANOVA } \\
\text { Test }\end{array}$} & \multirow{2}{*}{$\begin{array}{l}\text { P-value } \\
\text { and } \\
\text { Sig. }\end{array}$} \\
\hline Variables & \begin{tabular}{|l|} 
Mean \\
\pm SD \\
\end{tabular} & \begin{tabular}{|c|} 
Mean \\
$\pm S D$ \\
\end{tabular} & $\begin{array}{c}\text { Mean } \pm \\
\text { SD } \\
\end{array}$ & $\begin{array}{c}\text { Mean } \\
\pm \text { SD } \\
\end{array}$ & $\begin{array}{c}\text { Mean } \\
\pm \text { SD } \\
\end{array}$ & & \\
\hline $\begin{array}{l}\text { Mandibular } \\
\text { Angle Right }\end{array}$ & $\begin{array}{c}111.08 \\
\pm 3.19\end{array}$ & \begin{tabular}{|c|}
116.8 \\
5 \\
\pm 1.35 \\
\end{tabular} & $\begin{array}{l}119.0 \\
\pm 3.19\end{array}$ & $\begin{array}{c}121.55 \\
\pm 0.83\end{array}$ & $\begin{array}{c}127.58 \\
\pm 3.11\end{array}$ & $\begin{array}{c}\mathrm{F} \\
=157.4\end{array}$ & $\begin{array}{c}P=0.000 \\
V H S\end{array}$ \\
\hline $\begin{array}{c}\text { Mandibular } \\
\text { Angle Left }\end{array}$ & $\begin{array}{r}110.47 \\
\pm 2.76\end{array}$ & \begin{tabular}{|c|}
116.4 \\
2 \\
\pm 1.49
\end{tabular} & $\begin{array}{l}118.0 \\
\pm 2.76\end{array}$ & $\begin{array}{c}122.33 \\
\pm 1.88\end{array}$ & $\begin{array}{c}125.21 \\
\pm 3.33\end{array}$ & $\begin{array}{c}F \\
=120.6\end{array}$ & $\begin{array}{c}P=0.000 \\
V H S\end{array}$ \\
\hline $\begin{array}{c}\text { Length of } \\
\text { Ramus } \\
\text { Right }\end{array}$ & $\begin{array}{c}4.85 \\
\pm 0.36\end{array}$ & \begin{tabular}{|c|}
4.52 \\
\pm 0.55
\end{tabular} & $\begin{array}{c}4.37 \\
\pm 0.59\end{array}$ & $\begin{array}{r}4.45 \\
\pm 0.51\end{array}$ & $\begin{array}{c}4.05 \\
\pm 0.42\end{array}$ & $\begin{array}{c}F= \\
13.23\end{array}$ & $\begin{array}{c}P=0.000 \\
V H S\end{array}$ \\
\hline $\begin{array}{l}\text { Length of } \\
\text { Ramus Left }\end{array}$ & $\begin{array}{c}4.83 \\
\pm 0.34 \\
\end{array}$ & $\begin{array}{c}4.58 \\
\pm 0.54 \\
\end{array}$ & $\begin{array}{c}4.41 \\
\pm 0.60 \\
\end{array}$ & $\begin{array}{c}4.46 \\
\pm 0.49 \\
\end{array}$ & $\begin{array}{c}4.06 \\
\pm 0.43 \\
\end{array}$ & $\begin{array}{c}F= \\
12.08\end{array}$ & $\begin{array}{c}\mathrm{P}=0.000 \\
\mathrm{VHS}\end{array}$ \\
\hline $\begin{array}{l}\text { Bicondylar } \\
\text { Breadth }\end{array}$ & $\begin{array}{l}11.37 \\
\pm 0.73\end{array}$ & $\begin{array}{l}11.07 \\
\pm 0.98 \\
\end{array}$ & $\begin{array}{l}10.98 \\
\pm 0.97\end{array}$ & $\begin{array}{l}11.12 \\
\pm 0.48\end{array}$ & $\begin{array}{l}11.05 \\
\pm 0.71\end{array}$ & $\begin{array}{c}\mathrm{F}= \\
1.07\end{array}$ & $\begin{array}{c}P=0.408 \\
\text { NS }\end{array}$ \\
\hline $\begin{array}{l}\text { Bigonial } \\
\text { Width }\end{array}$ & $\begin{array}{c}9.43 \\
\pm 0.61\end{array}$ & \begin{tabular}{c|}
8.87 \\
\pm 1.15 \\
\end{tabular} & $\begin{array}{c}9.14 \\
\pm 0.85\end{array}$ & $\begin{array}{r}9.45 \\
\pm 0.61\end{array}$ & $\begin{array}{r}9.15 \\
\pm 0.65\end{array}$ & $\begin{array}{c}\mathrm{F}= \\
1.42\end{array}$ & $\begin{array}{c}\mathrm{P}=0.232 \\
\mathrm{NS}\end{array}$ \\
\hline & & & & & & & \\
\hline
\end{tabular}

NS= Not Significant, $\mathrm{S}=$ Significant, HS= Highly Significant, VHS= Very Highly Significant.

There was statistically very highly significant difference of mean right and mean left gonial angle in degrees in age groups ( $\mathrm{p}<0.001)$.

Mean of right and left gonial angle were significantly higher in higher age group.

There was statistically very highly significant difference of mean length of right ramus and mean length of left ramus in cms in age groups $(\mathrm{p}<0.001)$.

Mean length of right and left ramus were significantly lower in higher age groups.

There was no statistically significant difference of mean bicondylar breadth and mean bigonial width in cms in age groups $(\mathrm{p}>0.05)$.

\begin{tabular}{|c|c|c|c|c|}
\hline Variables & $\begin{array}{c}\text { Regression } \\
\text { Equation }\end{array}$ & $\mathbf{R}^{2}$ & $\begin{array}{c}\text { SE of } \\
\text { Estimate }\end{array}$ & $\begin{array}{l}\text { Correlation } \\
\text { Coefficient } \\
\text { and P-value }\end{array}$ \\
\hline $\begin{array}{l}\text { Mandibular } \\
\text { Angle }\end{array}$ & $\begin{array}{c}\text { Age group }=- \\
22.49+0.415 \mathrm{x} \\
\text { mandibular } \\
\text { angle value }\end{array}$ & $87.2 \%$ & 0.646 & $\begin{array}{c}r=0.927 \\
P<0.01 \\
H S\end{array}$ \\
\hline $\begin{array}{l}\text { Length of } \\
\text { Ramus }\end{array}$ & $\begin{array}{c}\text { Age group= } \\
10.83-1.77 \mathrm{x} \\
\text { length of } \\
\text { ramus value }\end{array}$ & $45.2 \%$ & 1.403 & $\begin{array}{c}r=-0.583 \\
\mathrm{P}<0.01 \\
\text { HS }\end{array}$ \\
\hline $\begin{array}{l}\text { Bicondylar } \\
\text { Breadth }\end{array}$ & $\begin{array}{c}\text { Age group= } \\
6.936-0.35 \mathrm{x} \\
\text { bicondylar } \\
\text { breadth }\end{array}$ & $2.7 \%$ & 1.702 & $\begin{array}{c}r=-0.164 \\
P>0.05 \\
N S\end{array}$ \\
\hline $\begin{array}{l}\text { Bigonial } \\
\text { Width }\end{array}$ & $\begin{array}{c}\text { Age group= } \\
5.59-0.284 \mathrm{x} \\
\text { bigonial width }\end{array}$ & $1.5 \%$ & 1.713 & $\begin{array}{c}r=-0.123 \\
P>0.05 \\
\text { NS }\end{array}$ \\
\hline
\end{tabular}

Here, $\mathrm{R}^{2}$ - Determination Co-Efficient, SE- Standard Error of the Estimate, Hs- Highly Significant, Ns- Not Significant.

Study reveals highly significant positive correlation between age and gonial angle $(\mathrm{p}<0.01)$.

Higher the mandibular angle with respect to age is also higher. 
There is highly significant negative correlation between age and length of ramus $(\mathrm{p}<0.01)$.

Lower the length of ramus with respect to age is higher.

There is no significant correlation between age and bicondylar breadth and bigonial width $(p>0.05)$.

\section{DISCUSSION}

The mandible consists of an arched horizontal body with a vertical process, the ramus, projecting upwards on each side from its posterior part. The angle is where the lower border of the body meets the posterior border of the ramus. The mandible ossifies in membrane round the cartilage of the $1^{\text {st }}$ pharyngeal arch. The process of ossification begins about the $6^{\text {th }}$ week of IUL. Accessory cartilage appears in the region of the condyle, coronoid process and symphysis and they are invaded by the adjacent membrane bone. At birth the right and left parts of the body are joined in front by fibrous tissue, the symphysis menti, but during the second year bony union is completed. The region of union is indicated by a median ridge. Two processes are seen projecting from the upper border of each ramus. The anterior one is the coronoid process for muscular attachment and the posterior one is the condylar process which has an articular part called the head. This articulates with the base of skull. The narrow part of condylar process inferior to the head is called the neck. The two processes are separated by the mandibular notch. The body has a smooth rounded inferior margin and an upper alveolar margin with sockets for the roots of the teeth. On the lateral surface is the mental foramen which in adults is midway between the upper and lower borders, below the interval between the premolar teeth or about $2.5 \mathrm{~cm}$ from the midline. The vertical ridge of symphysis menti expands below into a broad elevation, the mental protuberance that forms the prominence of the chin.11

At birth the two halves of the mandible are separated and the body of bone enclosing the developing teeth, which are not completely separated from each other. The mandibular canal and foramen are near the lower border and the foramen is opposite the cavity for the first milk molar tooth. The ramus is short, and the angle is very obtuse, so that the coronoid process is almost in line with the body. The halves begin to unite in the first year and union is completed in the second year. As the teeth erupt and the child begins to chew, the body becomes stronger and deeper, the rami enlarge and the angle becomes reduced to about 140 degrees by the fourth year. Progressive increase in depth and elongation, especially behind the mental foramen provides room for the permanent molars, the mental foramen assumes its adult position and the angle becomes reduced to $110^{\circ}$ or less. In old age, absorption of the sockets makes the chin appear prominent and the mental foramen is approached by the upper border. By remodeling the angle opens out again to 140 degrees and the condylar process is bent back, so that the mandibular notch is widened. ${ }^{12}$

The present study was mainly carried out to estimate age in 100 dry human mandibles using regression equation and also to correlate age with 4 parameters-gonial angle (Right and Left), length of ramus (Right and Left), bigonial width and bicondylar breadth.

The measurements and statistical analysis revealed that mean right gonial angle and mean left gonial angle have statistically significant difference. Gonial angle increased as age advanced and Ramus length decreased as age advanced, whereas bigonial width and bicondylar breadth were not statistically significant and have no correlation with age.

Statistically significant difference was observed between mean of right and mean of left gonial angle, which was analogous to the results obtained by Revanth Chole et al,13 V Poongodi et al,14 Jodi Leversha et al $^{15}$ and Upadhyay RB et al.16 But Jodi Leversha et al ${ }^{15}$ and Upadhyay RB et al ${ }^{16}$ study showed that it was not statistically significant.

There was very highly significant positive correlation between age and gonial angle in our study. This is in common with study done by Shilpa B et al,17 Payal Dhaka et al,18 Jodi Leversha et al,15 Ohm E and Silness et al, Tanveer Ahamed et al, ${ }^{19}$ DP Mohite et al, ${ }^{2}$ Roshanak Ghaffari et al ${ }^{20}$ and Shaw RB et al,21 but significant negative correlation between age and gonial angle was observed in studies done by Upadhyay RB et al 16 and Ogawa $\mathrm{T}$ et al.22 In study by Ogawa $\mathrm{T}$ et al,22 showed significant negative correlation between gonial angle and other variables.

In study by Payal Dhaka et $\mathrm{al}^{18}$ and Shilpa $\mathrm{B}$ et $\mathrm{al}^{17}$ ( $p>0.05$ ), though there is correlation between gonial angle and age, but it is not statistically significant. Revant $\mathrm{H}$ Chole et $\mathrm{al}^{13}(\mathrm{p}>0.05)$ and Noha Saleh et $\mathrm{al}^{23}$ came to the conclusion that there is no correlation between gonial angle and age.

Weinmann JP and Sicher $\mathrm{H}^{24}$ stated that the consecutive atrophy of the masticatory muscles in old edentulous people, after many years of increased function leads to changes in the region of the mandibular angle.

Mandible grows in a posterior superior direction, resulting in anterior-inferior displacement and that mandibular sagittal growth is due to anterior resorption in the ramus.

In our study, mean length of right ramus and mean length of left ramus showed statistically significant difference which is in accordance with study done by V Poongodi et al,14 but according to Noha Saleh et $\mathrm{al}^{23}$ Jodi leversha et al,15 Huumonen $\mathrm{S}$ et $\mathrm{al}^{5}$ and Shamout et $\mathrm{al}^{25}$ there is no statistically significant difference in mean of right and left ramus length.

According to our study, there is negative correlation between the length of ramus and age, which is statistically significant and is similar to Shamout et al 25 study, where ramus height decreased with age after 29 years of age. Oksaya et al,26 Jodi leversha et al,15 Tanveer Ahamed et al,19 and Huumonen et $\mathrm{al}^{5}$ also favour the same result as of our study. Whereas according to Noha Saleh et al, ${ }^{23}$ Shamout et $\mathrm{al}^{25} \mathrm{~V}$ Poongodi et al ${ }^{14}$ and DP Mohite et al, 2 there is positive correlation between age and length of ramus. Shamout et al 25 stated that ramus height increases with age upto 29 years.

The correlation between age and length of ramus is statistically significant in our study, which is in accordance to study done by Noha Saleh et al,23 in which stepwise regression analysis showed statistically significant correlation, but when compared between actual and estimated age correlation between length of ramus and age was not statistically significant. DP Mohite et $\mathrm{al}^{2}$ and Roshanak Ghaffari et al ${ }^{20}$ also stated in their study that correlation between age and length of ramus was not statistically significant. Mandible continues to grow. Shape changes because some areas continue to grow faster than other areas. This is in accordance with the principle of differential growth of the facial skeleton. 
In our study, bigonial width and bicondylar breadth are not useful to estimate age and are not correlated statistically with age. But in study done by Khalid et al ${ }^{27}$ and Shamout et $\mathrm{al}, 25$ there is positive correlation between age and bigonial width, which is completely not in favour with study done by Jodi Leversha et al.15 According to this author, there is negative correlation between age and bigonial width and is not statistically significant. Whereas according to Roshanak Ghaffari et al20 and Shaw et al they also came to the conclusion in their studies that correlation between age and bigonial width is not statistically significant.

Bicondylar breadth was also a parameter, which did not correlate with age and was unable to estimate age with its measurements in our study. Khalid et al 27 found a positive correlation between age and bicondylar breadth, which is statistically significant $(p<0.000)$. Correlation co-efficient showed relation between age and bicondylar breadth $\left(\mathrm{R}^{2}=0.360\right)$.

\section{CONCLUSION}

Estimation of age by regression equation and correlation of age with mandibular parameters have an implication in field of forensic science, orthodontics and anthropology. Thus, in our study we found that as age increases gonial angle also increases, length of ramus decreases with age. There is no correlation of age with bicondylar breadth and bigonial width and they cannot be the main factors to consider them as predictors for age determination.

\section{REFERENCES}

[1] Rai B, Anand S, Madan M, et al. Criteria for determination of sex from mandible. The Internet Journal of Dental Science 2007;4(2):1-5.

[2] Mohite DP, Choudary MS, Mohite PM, et al. Age assessment from mandible: comparison of radiographic and histologic methods. Rom J Morphol Embryol 2011;52(2):659-68.

[3] Prabhu SR, Wilson DF, Daftary DK, et al. Oral diseases in the trophics. Oxford: Oxford University Press 1993: p. 758-9.

[4] Dudar JC, Pfeiffer S, Saunders SR. Evaluation of morphological and histological adult skeletal age to death estimation techniques using ribs. J Forensic Sci 1993;38(3):677-85.

[5] Huumonen S, Sipila K, Haikola B, et al. Influence of edentulousness on gonial angle, ramus and condylar height. J Oral Rehabil 2010;37(1):34-8.

[6] Fish SF. Change in the gonial angle. Journal of Oral Rehabilitation 1979;6(3):219-27.

[7] Casey DM, Emrich LJ. Changes in the mandibular angle in the edentulous state. The Journal of Prosthetic Dentistry 1988;59(3):373-80.

[8] Ohm E, Silness J. Size of the mandibular jaw angle related to age, tooth retention and gender. Journal of Oral Rehabilitation 1999;26(11):883-91.

[9] Mattila K, Altonen M, Haavikko K. Determination of the gonial angle from the orthopantomogram. Angle Orthodontist 1977;47(2):107-10.

[10] Dutra V, Yang J, Devlin H, et al. Mandibular bone remodelling in adults: evaluation of panoramic radiographs. Dentomaxillofacial Radiology 2004;33 (5):323-8.
[11] Causey G, Young JZ, Joseph J, et al. A manual of human anatomy. $2^{\text {nd }}$ edn. E \& S Livingstone Ltd., 1968: p. 26-7.

[12] Romanes GJ. Cunningham's textbook of Anatomy. 10 edn. London: Oxford University Press 1964: p. 124.

[13] Chole RH, Patil RN, Chole BS, et al. Association of mandible anatomy with age, gender and dental status: a radiographic study. ISRN Radiol 2013;2013:453763.

[14] Poongodi V, Kanmani R, Anandi MS, et al. Prediction of age and gender using digital radiographic method: a retrospective study. J Pharm Bioallied Sci 2015;7(Suppl 2):S504-8.

[15] Leversha J, Mckeough G, Myrteza A, et al. Age and gender correlation of gonial angle, ramus height and bigonial width in dentate subjects in a dental school in Far North Queensland. J Clin Exp Dent 2016;8(1):e49e54.

[16] Upadhyay RB, Upadhyay J, Agarwal P, et al. Analysis of gonial angle in relation to age, gender and dentition status by radiological and anthropological methods. J Forensic Dent Sci 2012;4(1):29-33.

[17] Shilpa B, Srivastava SK, Sharma RK, et al. Combined effect of age and sex on the gonial angle of mandible in North-Indian population. Journal of Surgical Academia 2014;4(2):14-20.

[18] Dhaka P, Mathur E, Sareen M, et al. Age and gender estimation from mandible using lateral cephalogram. CHRISMED J Health Res 2015;2(3):208-11.

[19] Khan TA, Sharieff JH, Quadri SS. Study of age determining factors of mandible in 200 south Indian subjects. Anatomica Karnataka 2012;6(1):88-91.

[20] Ghaffari R, Hosseinzade A, Zarabi H, et al. Mandibular dimensional changes with aging in three dimensional computed tomographic study in 21 to 50 years old men and women. Journal of Dentomaxillofacial Radiology Pathology and Surgery 2013;2(1):7-12.

[21] Shaw RB Jr, Katzel EB, Koltz PF, et al. Aging of the facial skeleton: aesthetic implications and rejuvenation strategies. Plast Reconctr Surg 2011;127(1):374-83.

[22] Ogawa T, Osato S, Shishido Y, et al. Relationships between the gonial angle and mandibular ramus morphology in dentate subjects: a panoramic radiophotometric study. J Oral Implantol 2012;38(3):203-10.

[23] Abu-Taleb NS, El Beshlawy DM. Mandibular ramus and gonial angle measurement as predictors of sex and age in an Egyptian population sample: a digital panoramic study. J forensic Res 2015;6(5):308.

[24] Weinmann JP, Sicher H. Bone and bone, fundamentals of bone biology. St. Louis: The CV Mosby Co, 1947: p. 178-80.

[25] Shamout RA, Ammoush M, Alrbata R, et al. Age and gender differences in gonial angle, ramus height and bigonial width in dentate subjects. Pak Oral Dent J 2012;32(1):81-7.

[26] Oksaya R, Aktan AM, Sokucu O, et al. Does the panoramic radiography have the power to identify the gonial angle in orthodontics? Article ID 219708, Scientific World Journal 2012;(2012): p. 4.

[27] Ahmed KM, Ayad C. Normative morphology of adult Sudanese mandible: a 3D computerized tomographic based study. IOSR Journal of Dental and Medical Sciences 2016;15(7):82-7. 